\title{
INSTRUCTIONS FROM THE ADMINISTRATIVE DEPARTMENT OF PUBLIC SERVICE'S FIRST CIVIL SERVICE EXAMINATION FOR NURSING: REVELATIONS FROM 1941
}

\author{
Danilo Fernandes Brasileiro ${ }^{1}$, Maria Cristina Sanna ${ }^{2}$
}

\begin{abstract}
${ }^{1}$ Specialist in Intensive Care. Nurse, Hospital das Clinicas, Faculty of Medicine, Universidade Federal de São Paulo. São Paulo, São Paulo, Brazil. danilo.brasileiro@hc.fm.usp.br

${ }^{2}$ Ph.D. in Nursing. Independent researcher. Professor and guidance counselor in the graduate program of the Paulista School of Nursing, Universidade Federal de São Paulo. São Paulo, São Paulo, Brazil. E-mail: mcsanna@uol.com.br
\end{abstract}

\begin{abstract}
The aim of this study was to describe the primary norms and instructions for the first civil service exam for nurses administered by the Administrative Department of Public Service. This is a descriptive and historical-documentary study. Sources included publications about the event in the Diário Oficial da União, Brazil's Federal Official Gazette. Analysis and construction of results adhered to the sequence of presentation of norms and instructions of the process. Three were decrees that regulated the first civil service exam: two were generalized (n. 661 and n. 1411) and one was specialized (n. 1360). The specific instructions contained in the specialized decree were highlighted, and distributed in three chapters: I-Conditions; II-Exams; and III-Evaluations. In the Vargas Era, a substantial number of public servant positions for nurses were filled by way of public civil service exams administrated by the Administrative Department of Public Service, underpinned by rigorous normative structure, and translated into detailed selection criteria. DECRIPTORS: History of nursing. Personnel selection. Public administration.
\end{abstract}

\section{INSTRUÇÕES DO PRIMEIRO CONCURSO PARA ENFERMEIROS DO DEPARTAMENTO ADMINISTRATIVO DO SERVIÇO PÚBLICO: REVELAÇÕES DATADAS DE 1941}

\begin{abstract}
RESUMO: Objetivou-se descrever as principais normas e instruções do primeiro concurso para a carreira de enfermeiro realizado pelo Departamento Administrativo do Serviço Público (DASP). Pesquisa descritiva histórico-documental. As fontes utilizadas foram publicações sobre o certame no Diário Oficial da União. A análise e construção dos resultados obedeceu à sequência de apresentação das normas e instruções do processo. Três foram as portarias que regulamentaram o primeiro concurso: duas de ordem geral - a $n$. 661 e a n. 1.411, e uma de ordem especial - a de n. 1.360. Destacaram-se as instruções normativas específicas contidas na portaria de ordem especial, distribuídas em três capítulos: I- Das Condições; II- Das Provas; e III- Dos Julgamentos. Boa parte dos cargos públicos para enfermeiros, no Estado Novo, passou a ser preenchida por meio de concursos públicos efetuados pelo DASP, sustentados por rigorosa estrutura normativa, traduzida em critérios de seleção minuciosamente descritos.
\end{abstract}

DESCRITORES: História da enfermagem. Seleção de pessoal. Administração pública.

\section{HAGA CLIC EN EL CERRAR CONCURSO PARA LAS ENFERMERAS DEL DEPARTAMENTO ADMINISTRATIVO DE LA FUNCIÓN PÚBLICA: REVELACIONES DE FECHA 1941}

RESUMEN: El objetivo es describir las principales normas e instrucciones del primer concurso para la carrera de enfermería, realizado por el Departamento Administrativo de la Función Pública. Se trata de investigación descriptiva, histórico documental. Las fuentes utilizadas fueron las publicaciones sobre el concurso en el Diario Oficial. El análisis y la construcción de los resultados fueron hechos de acuerdo con la secuencia de presentación de normas e instrucciones del proceso. Tres actos administrativos regularon el primer concurso: dos de orden general, el número 661 y el 1.411, y uno de orden especial - el n. 1.360. Fueron destacadas las instrucciones normativas específicas que se encontraban en el acto administrativo de orden especial, distribuidas en tres capítulos: I - De las condiciones; II - de las pruebas; III - de los juicios. Gran parte de los cargos públicos para enfermeros, el Nuevo Estado, fue ocupado a través de los concursos públicos del Departamento Administrativo de la Función Pública, sostenidos por una estructura normativa rigurosa, traducido a los criterios de selección descritos en detalle

DESCRIPTORES: Historia de la enfermería. Selección de personal. Administración pública. 


\section{INTRODUCTION}

The historical roots of the merit-based selection system for public employment goes back to Chinese society between the sixth and fifth centuries BC. In addition to all of Europe, between the fourteenth and sixteenth centuries during the humanist period, China, through the "Chinese scholars," made literary education a resource to attain social prestige, whereby even a commoner could become a scholar, as long as he accessed the Chinese writing system. The scholars broke with the paradigm of social positioning through heredity (nepotism), supporting themselves by their competence and level of education, because they worked as opponents of the feudal system and were proponents of state bureaucracy, so much so that, in the late seventh century, all categories of public servants were recruited and qualified for positions according to merit achieved after undergoing several exams. ${ }^{1}$

In the twelfth and thirteenth centuries in Europe, with the emergence of the university and adoption of exams as a mechanism of entry, greater union between the principles of merit and knowledge was established, because graduates of universities who obtained doctoral degrees automatically occupied the most coveted jobs. During the French Revolution from 1789 to 1799, the Enlightenment concept of merit to obtain public office was disseminated throughout Europe, leading to the creation of strict rules to ensure the rights of candidates and the obligations of the government against mistakes in selection judgments. Although adoption of the principle of merit and the exam-based selection mechanism gained increasing support in Europe, reproducing the interest of the capitalist mode of production, in the urge to select candidates through competition and selection of the most capable, until the mid-nineteenth century, countries like Germany and England continued to treat public offices as objects for political gain..$^{2-3}$

In Colonial Brazil, between 1530 and 1815, public office was treated in a manner opposite to the social concept of work as an activity of collective good, and remained a mechanism of cronyism, nepotism and job security for the benefit of the occupants of government positions, a practice that continued until the mid-1930s, except for rare exceptions that took shape in the meantime, for example, the civil service exam of the National Treasury, regulated by the Law of October 4, 1831.2-4
During the Vargas dictatorship the panorama changed, more specifically by Decree Law N. 579 of July 30, 1938, when the Administrative Department of Public Service (DASP, as per its acronym in Portuguese) was established, ${ }^{5}$ which defined a new set of policies for public personnel, and led the transition from clientelist in Brazil, marked by waste and the "pistol", towards a democratic model focused on efficiency and careful selection of candidates for public office. ${ }^{6}$

The DASP civil service exams were administrated to fill vacancies in various professions, including nursing. However, in 1941, the Brazilian Association of Nursing Graduates (ABED, as per its acronym in Portuguese), later called the Brazilian Nursing Association (ABEn, as per its acronym in Portuguese), took a position against the public service exams proposed by the DASP, based on the theory that such a selection process could be disputed by practicing nurses who were not graduates of the discipline. Apparently the differences were attenuated and the interests administered, because evidence suggests the above event took place in order to effectively fill nursing vacancies in various ministries, and, as far as it is known, this was the first one for nurses, here considered those with higher education, nationwide. ${ }^{7}$

Although the civil service exam is not a foolproof method of recruitment and selection for public service, there is consensus that it is the best alternative ever devised for selecting candidates for these positions, because their rigorous execution indicates the attainment of important principles of the Brazilian constitutional system. ${ }^{4}$ However, it is not enough to recognize the important role the civil service exam plays in selecting candidates for public office if it does not sustain itself by means of a rigorous regulatory framework, considered the "Law" of the public exam, and best known as "Public Notice," this being the most important administrative act of the whole process, composed of written instructions that contain legal information, and must provide rules on the competition, taking into account constitutional principles. ${ }^{3-8}$

The authors of this study, upon learning of the occurrence of such a selection process and considering its hypothetical historical and social representation, were especially interested in the structure that supported and regulated the event, which culminated in the following research question: what are the main normative instructions presented in the official notice of the first civil service exam to fill nursing vacancies promoted by the DASP? 
The justifications for the realization of this study included: novelty of the theme, lack of a study in the Brazilian scientific literature that addresses the selection of nurses by the DASP; the theme itself as scientific interest, since the DASP was a milestone in the initiative of government remodeling in Brazil, and among other professional classes, considered nursing through merit-based selection; and because knowledge of the regulatory and structural framework of the first civil service exam for nurses at the national level will enable understanding of a nationally regulated practice, from that time, and which is still used at the municipal, state and federal levels as the primary mechanism to fill vacancies of minor and major importance, for various professions, including nursing.

Thus, this study aimed to describe the main rules and instructions in the official notice of the first civil service exam administered by the DASP to fill nursing vacancies.

\section{METHODOLOGY}

This was a descriptive, historical-documentary study, understood as that which, through systematic collection and thorough evaluation of data on what has already occurred, aims to answer questions concerning the causes or trends of past events that may shed light on current behavior or practices. ${ }^{9}$

Direct data sources of the study included copies of the Diário Oficial da União [Official Gazette of the Union], which contained the official notices that regulated the first civil service exam for nurses administered by the DASP. The identification of these records began through online consultation on the JusBrasil (Jurisprudence Brazil) website, which has a large amount of legal documents including official journals, court decisions, normative acts, and informative and doctrinal articles. ${ }^{10}$ The query to the aforementioned online database complied with the time frame defined between 1938, when the DASP began its work, and 1945, when there was a drastic reduction of its activities for selection of human resources, and the agency began to perform primarily advisory activities. Thus, because the database employs cutting-edge technology that was internationally recognized in 2007 by ReadWriteWeb as one of the 10 best alternative web search engines to Google, ${ }^{10}$ relying on its quality, an initial search was conducted with the Portuguese expression "Concurso de Enfermeiros do DASP" ["Nurses Civil Service Examination of the DASP"]. This query generated about sixty hits, and after refinement, it was possible to build a research network, and then conduct a search with the names of the three Ordinances and their respective official notices, which regulated the first civil service exam for the initial career of nurse administered by the DASP. These documents were downloaded in PDF format, then printed and taken to the national archives in the city of Rio de Janeiro and compared to the originals, in order to obtain their certification of authenticity.

Other document sources were used, which were collected in the city of Rio de Janeiro during the month of January 2014, and were part of the "Gustavo Capanema" documents collection of the [Center for Research and Documentation of Contemporary Brazilian History of the Getulio Vargas Foundation (CPDOC-FGV) and the DASP Fund collection of the National Archives.

After data collection proceeded analysis, which began with repeated individual readings of the three official notices, two of which were generalized and one of which was specifically related to the exam under study, governing the said civil service exam. These readings were according to a predetermined script for each of the notices, since they enabled the authors to gradually select those that they understood to be the main normative regulatory instructions of the event. With the individual scripts duly filled out, the authors met and compared each one, standardizing the findings according to similarity and thematic relevance of information, an action that enabled the construction of a single script, whose categorization of findings among the three official notices maintained similarity with the titles of the chapters of the notice of special order for the nurses civil service exam. The findings were then sequentially described and discussed based on the appropriate scientific literature.

As per current legislation, because this is a study of available data records, submission of the project to a Human Research Ethics Committee was not necessary. ${ }^{11}$

\section{RESULTS AND DISCUSSION}

This competition was regulated by three decrees and their respective public notices, one of which was specific to nursing and two of which were general to civil service exams. Special decree n. 1,360 12 of September 18, 1941 regulated the event under study, and general orders n. $661^{13}$ 
and n. 1,411 ${ }^{14}$ of July 2, 1940 and October 7, 1941, respectively, regulated all public service exams administered by the DASP.

Once the norms were stipulated by the general ministerial decrees, it was the responsibility of the specific committees of the civil service exams to define the application and adaptation of such rules, taking into account the specificities of their selection processes. The contents of the Decree N. 1,360 of September 18, 1941, which set specific guidelines for the first civil service exam for appointment to offices of the initial class of nursing career of any ministry, is detailed in three chapters: I - Conditions; II - Examinations; and III - Evaluations. In addition, this decree had two annexes related to the instructions and evaluative content: I - Schedule of Selection Practice Exam; and II Schedule of Written Exam.

A legal framework that supported the activities related to candidate selection is observed, which was undoubtedly pioneering at the time, in what can be considered the precursor of current official notices for public service exams. This finding indicates it was composed of an impressive normative framework, supporting the assertion that official notices are the concrete representation of the principle of legality of the event and the most important component of the whole process, because, in addition to stipulating rules that both candidates and public administration would adhere to, a control was ensured along with constitutional principles such as equality, morality, reasonableness, impersonality, efficiency, publicity, proportionality and broad accessibility to public service. ${ }^{8}$

Chapter I of the special instructions, "Conditions," was only composed of a single article and paragraph, and addressed the basic premises for participation in the stated selection process: applicants must be aged between 21 and 35 years, and upon registration, should submit their nursing degree, issued by an official or officially-recognized school. It is notable that such special instructions were not very strict, however, they allowed participation of nurses of both sexes, duly graduates of the standard official school, the Escola de Enfermagem Anna Nery or equivalent, thus meeting the requirements of Decree N. 20109 of $1931 .{ }^{15}$

The fact that the inclusion criteria did not discriminate by gender is further indication of actions that reshaped the profession of nursing during the Vargas Era. In the historical panorama of growing industrialization and transition from a model centered on public health practice to hospital care, it was necessary to insert black men and women into nursing, breaking with the ideal standard of development of the profession, hitherto marked by distinction between genders, and the practice of which was distinctly conceived of as feminine. ${ }^{16-17}$

It should be added that Chapter VII of the 1934 Constituent, ${ }^{3}$ which was dedicated to the regulation of civil service relations, defined in Article 168 that accessibility to public office was guaranteed to all Brazilians, regardless of sex or marital status, as a criterion for appointment to public office. However, it was found that for male candidates, there was a type of reserve of vacancies, that is, they benefited from decree-law No. 1,963 of January 13, 1940, which allowed them to assume public office, as established in its Article 1 thereof: "By this law, graduates and sergeants of the Army and Navy, of good conduct and proven physical fitness, who have served for more than five consecutive years, are assured employment as federal employees." ${ }^{18}$ Although in this case gender discrimination did not occur, it is understood that due to the Second World War (1939-1945), it was of strategic interest to stimulate the insertion of the male workers into nursing, albeit still aligned to the needs of the internal front. ${ }^{17}$

As regards upper age limit of the candidates, it is believed that because it was the first selection process for entry of these professionals into public service, combined with the need for productive labor due to the greater period of possible activity, the stipulation of this requirement was considered desirable. It should be noted that this practice was legal until the mid-1950s, when the premise emerged that determination of age limit undermined the principle of free competition among citizens, so much so that the Law no. 5,017, of December 16, $1958,{ }^{19}$ which delegated powers to establish age limit to the government in order to administer public service exams, was repealed by opinion no. 14 of the Brazilian Supreme Court, ${ }^{3}$ which understood this delegation to be unconstitutional: "It is not acceptable, by an administrative act, to restrict, on grounds of age, competition in civil service exam for public office." Furthermore, Art. 7 of the Federal Constitution stipulated that the establishment of age limits is only lawful in the presence of a dependent relationship among the occupational duties of the position to be filled. ${ }^{3}$

Presentation of degree upon registration was the subject of extensive discussions. Because it was considered that the candidate should be 
professionally qualified to perform the required work, presenting the degree at registration enabled the government to avoid later problems, because it would be a problem for the government if the successful candidate did not possess such qualification. This consensus prevailed for some time, but currently, as recommended by Precedent $\mathrm{n}$. 266 of the Supreme Court, " "The degree of legal qualification for exercising the position should be required only upon hiring and not at registration for the civil service exam."

Also as regards registration for the exam, the general provisions complemented the above agenda, because Decree n. 661 of July 2, 1940,11 in its first chapter on registrations, on the dissemination of official notices, holds that these should be published three times in the Official Gazette and in newspapers with large circulation. In addition, Decree 661 specifies, in a single paragraph, that registrations were only performed by presentation of documents, including proof of Brazilian nationality, certificate of civil registration or marriage, naturalization title, military service certificate, official identification card, professional card or voter registration card, and smallpox vaccination or revaccination certificate dated a maximum of two years, from the health authority. On the dissemination of official notices, it is known that although the principle of economy is currently practiced, and the publication of notices in various media is reduced, it is essential to do this in at least one official vehicle with wide distribution to adhere to the principle of publicity. ${ }^{8}$

The special guidelines of the second chapter, "Examinations," consisted of six articles on selection and qualification exams. The selection exams were the first to be held and included two subtypes: the first, proof of health and physical capacity, was related to the organic conditions of the candidates, and set a strict level of requirement, conditioned on biological status, as seen in the reproduction of Art. 3 " [...] a) proof of health and physical capacity by which it is verified that the candidate does not have communicable diseases, organic or functional changes in facilities or equipment, nor contraindications for the exercise of the office due to morphological or functional anomaly [...]."

At the time an established practice in the admission regulations for students to nursing schools ${ }^{20}$ the application of health and physical capacity exams was also used in the selection of civil servants. The accuracy of the tests was rigorous, because if the candidate was stricken with tuberculosis, leprosy, cancer and/or syphilis, among other diseases, she/he was automatically eliminated from the public service exam. Although this eliminatory rigor prevailed, given the inadequacy of candidates in relation to the established criteria, consideration was given to the singularities of each profession. That is, a blind person could not undergo a civil service exam for designer, but was not prevented from participating in exams for other professions, so much so that there were special DASP exams for candidates with visual, among other, impairments. ${ }^{4}$ There are a lot of controversies on this issue, however, the disagreements must be eased, because given current legislation, the selection process under review did not undermine the principle of equality of citizens, as this was applied in the sense of candidate's skill during his investiture in public office, not in terms of classificatory interference, a use that is currently illegal. ${ }^{2-3}$

The second subtype of selection exam, the service practice exam, lasting a maximum of one hour, consisted of two techniques selected from the total of twelve, followed by preparation of a report, at the end of execution of the practices. Of these twelve techniques, eleven confirmed the predominance of the semiotechnique, focusing on practical hospital care, and only one focused on public health practice.

After execution of the selection exams, the next step consisted of taking qualification exams, because it was assumed that the candidates had already been recruited taking into account the defined requirements and, therefore, would be able to pass through more specific phases of the event. The qualification exam was also composed of two subtypes: the first was a written exam and the second, considered optional, consisted in the candidate's submission of complementary proof of title. The written tests had a stipulated time of about three hours, and consisted of about ten theoretical questions selected by the candidate from 15 specified in advance.

Such exams (written and practical) are proposed to analyze knowledge from the perspective of different skills, so much so that there was little dissonance between the two, because, despite the content of the written exam referring to general nursing skills, and addressing issues of public health, ethics and mental health, and the practical test was limited almost exclusively to hospital health care practice, the contents of both revealed 
that the vision of what was expected of nurses, in order to work in public service, was solely and exclusively related to care practice.

The above statement can be justified from studies that examined the content of the curricula of official nursing schools during that period. In fact, the first curricula practiced in the Anna Nery School of Nursing in 1923 and 1937, and the first curriculum of the São Paulo Hospital School of Nursing in 1949, received strong influence from the North American model of nurse training, structured with a large number of theoretical disciplines with low workload and heavy workload of health care practice, based on the biomedical model of care for an institutionalized clientele. ${ }^{21-22}$

The supplementary proof of titles, as already mentioned, was optional to the candidate and consisted in presentation of diplomas, school records, including grades obtained, and certificates attesting to professional experience, as per that set forth in Art. 4: "The candidate can attach proof of professional work, as long as it is for more than one year of actual work and from an official office or hospital, as well as from a renowned private hospital, at the discrepancy of the evaluator."

Proof of employment would have been considered useful in the classification process, provided it did not assume significant import and weight so that certain candidates gained advantage. In addition, the titles of employment should have been required and validated only if it was correlated with the job in dispute. Based on the previous statement, which provides coherence between requesting employment titles and the functions to be performed, it is clear that the candidates to be selected would be directed to hospitals; thus, the candidates' work experience in these types of organizations was specified, particularly those that were renowned.

Among the instructions on tests and exams presented in the decree of special specifications, conduct in light of the occurrence of unlawful acts during the execution of this phase of the event was not regulated at any time, because guidelines of this nature were contingent only on general Decree $\mathrm{N}$. 661 of July 2, 1940,13 which were expressed in Art. 13: "The candidates who, during the course of any of the tests, are caught in the act of communicating with other candidates or strange people, verbally, in writing or by any other form, or using books, prints or notes, except as expressly permitted, will be eliminated from the competition, by act of the Examining Board, or the Executive Committee."
It also mentions that the organizational intention of applying the selection and qualification exams was to maintain the requirements for exams consistent with the duties of the office, applying criteria of reasonableness, fairness, free competition and efficiency. However, it was noticed that the values and positions held by them in the civil service exam in question were the reverse of what is practiced in the current selection process, leading to the assumption that practical tests succumbed to the consideration given to the theoretical tests, in which the second assumes strategic superiority and classification over the former. It is understood that both should be allocated at the same stage of the event, since the reproduction of the intellectual division of labor is not considered coherent, especially in the candidate's admission phase, which can be attributed to the "academicism" still operating in Brazil. ${ }^{3,23}$

Chapter III - "Evaluations", contains special instructions composed of nineteen articles which outline the criteria for evaluating the exams (health, practice, writing and qualification), with the result of the evaluations expressed on a scale of 100 points, and also indicates precepts related to conclusions and dissemination of results. Arbitration on the evidence of health and physical capacity was based on criteria established by technicians of the Medical Biometry service of the National Institute of Pedagogical Studies, which authorized or unauthorized applicants. Authorized applicants underwent the practical test, the result of which attributed up to seventy points for technical performance and thirty points for the report resulting from the practice. Applicants then underwent the written test, consisting of ten questions worth ten points each. Passing this exam required a minimum score of seventy points.

Proof of qualification occurred concomitantly with the other tests. In this process, the candidates were invited to submit their formal qualifications at a predetermined place, date and time, when they had to submit these qualifications in two copies, with a typewritten list provided upon registration. A copy of the list was for the exam board and the other was returned to the applicant with an attached receipt. Assessment of the qualifications adhered to established criteria, and was scored on a scale of 100 . In order to pass, the candidate had to receive a score of sixty points or more. The exam boards were composed of five examiners, defined as per the general instructions of Article 21 of Decree N. 661 of July 2, 1940, ${ }^{11}$ which 
regulated them: "The exam boards are made up of people of good moral and capacity, appointed by the President of the DASP based on proposal by the Selection Service Director."

Definition of the exam boards of every public service exam, as was specified in this one, had to be regulated by administrative acts in the form of decrees or ordinances, with prior appointment of the chairman, deputy chairman and other members, and making sure that the boards were always composed of experts in the field of the office to be filled. In this case, the exam board was composed of five members, including Marina Bandeira de Oliveira, ${ }^{24}$ a nurse who was president of ABEn between April 1947 and July 1948, and José Paranhos Fontenelle, doctor of the National Department of Public Health and professor at the Ana Nery Nursing School, responsible for the first pedagogical studies based on intelligence tests. ${ }^{25}$

Classification and final grade were based on the mean of the scores obtained, according to the order of score by weight: the practice test and proof of qualifications had weights of 2 each, and the written score had a weight of 1 . If there was discrepancy of more than 20 points between the scores assigned on any of the tests by different examiners, each had to justify their judgment in writing. If there was a tie between candidates, the criterion of order of preference was applied: 1st place (best result in the practical exam); 2nd place (best result in the test of qualifications); and 3rd place (best result in the written test).

After approval, the result of the civil service exam was valid for two years, and the candidate, upon registration and becoming aware of the proposed criteria, automatically declared their consent to the rules defined in the official notice. The validity period observed in this event is the same as is currently recommended, as per article 37, section III of the Federal Constitution, which establishes a maximum period of two years after approval, with rare exceptions, for example, when there is legal prescription or official notice of doubled term. The establishment of term and extension adhered to the principle of economy and automatic facilitation of public administration because, as long as the positions remained open, they could be filled automatically without the need to perform another civil service exam..$^{2-3}$

There is concern expressed in the general provisions that addressed the resources confronting the final judgment in the selection process, because the official notice defined that the candidate would have until 24 hours after the announcement of results of the tests to apply to the Department of Selection, so that possible cancellation of the event was called for in the event of proven fraud, as called for by the Ordinance of General Instructions N. 661 of July 2, 1940, through its Chapter IV - "On Test Evaluations and Qualification of Candidates": "Art. $29 \S 2^{\circ}$ : If addiction, irresolvable irregularity or infringement of essential procedural requirement is proven, the civil exam will be canceled, partially or totally, and those to blame will be held responsible." The focus on determining irregularities that may occur and generate doubts about the fairness of the selection process is notable, an attitude not unlike today, because when analysis is performed of the public admission process via civil service exam, and any illicit act is detected, the consideration of principles of legality and merit is confirmed, leaving only the act of approval. However, if illegality is proven at any stage of the proceedings, one should, where possible, not cancel the entire process, but only the phases that were executed from the illegal act, as it is of interest to the public administration that the exam proceed, in order to fill the vacancies for public service.

On the specifics of the notices, the absence of prior determination of the values of salaries for the position in dispute is notable, although at that time, there was already a classification of positions and functions of Federal Public Service employees, determined by specific legislation, that framed the professions, their progression levels and income and in classification standards represented by letters and Roman numerals.

Thus, when querying the said legislationDecree N. 9,808, of June 30, 1942, ${ }^{26}$ the career of nurse, dentist, statistician, researcher, among others, on a scale of salary reference for all federal public servants, between the functional series I and XXII, occupied the positions between VII and XI, which meant that their incomes were stipulated between $400 \$ 0$ (four hundred contos de Reis) and $600 \$ 0$ (six hundred contos de Reis). Based on this information, one can deepen the discussion, and at least hypothetically say that salaries were not as low as other professionals, because this can be compared to the physician's income, between the functional series XII and XVII, i.e. $700 \$ 0$ (seven hundred contos de Reis) to 1:100\$0 (one conto de Rei and a hundred contos de Reis). ${ }^{27}$ For illustrative and informational purposes, we opted to not convert the values of Reis into the current Brazilian 
currency of reais, but, to give you an idea of the value of the Rei, this was based on the price of a sack of sugar (sixty kilograms) which, on June 27, 1942, was between $67 \$ 0$ (sixty-seven contos de Reis) and $70 \$ 0$ (seventy contos de Reis). ${ }^{27}$

This was the presentation of the legal framework for administering the first civil service exam for nurses by DASP, a construct developed with care and objectivity, characteristic of the intentionality of organization of this activity in public service.

\section{CONCLUSION}

Most federal public positions for nurses in the Vargas Era began to be filled by way of public civil service exams administered by the DASP. The legal structure of the event resulted in its official notices, tools that, in addition to regulating a process of recruitment and selection of human resources for professional public vacancies, transcended their function, because they increased innovations relating to legal standardization of civil service exams in the country at the time.

Despite the text of the public notice having been published more than seventy years ago, its actuality is impressive. In order to not commit anachronism, without weaving comparisons or to disregard the changes and quirks of current edicts, it is registered that the phenomenon is dated and adhered to orders of the day, but risks to recognize the influence of such an event in the ideological matrix which reinforces current civil exams of the same nature. It is also noted that its guidelines adhered to principles that remain current today: transparency, publicity, legality, free competition and reasonableness, among others, are valued and aimed for in all public service exams today.

On the specifics of the edicts, the absence of the values of the salaries corresponding to the position in dispute is noted, although there was a structure of positions and careers which defined the initial grading and salaries, respectively. The absence of a set of references defined in the official notices was also noted, because the contents proposed for the implementation of theoretical and practical tests were just described and detailed in an inadequate manner. The lack of human resources in nursing was clear, when considering the omission of stipulation of the number of vacancies, which suggests the continued hiring of those candidates who passed during the period of validity of the exam. It is worth mentioning that, apparently, the jobs to be filled were concentrated in hospital care.

This was a first approach on the theme, which allowed for knowing, albeit in part, its structural framework. However, the limitations that permeated the undertaking of the study must be considered, because it was based only on historical sources, because these were the only sources available, but which undoubtedly did not disqualify its undertaking. Thus, it is suggested that in-depth studies are conducted, especially with regard to the results of the selection processes of the DASP, so that there are new studies that respond to issues raised here, or related to other selection processes that may have occurred during the same period or any subsequent period, so that the structure, criteria for classification, the results and the number of approved and eliminated candidates can be known, along with other specificities, which undoubtedly will help fill in gaps of knowledge about this practice.

\section{REFERENCES}

1. Weber $\mathrm{m}$. The Chinese literati. In: Fernandes F. Ensaios de sociologia geral. Rio de Janeiro (RJ): Guanabara; 1982.

2. Vieira LCA. Merecimento na Administração Pública: concurso público, avaliação de desempenho e política pública de pessoal. Belo Horizonte (BH): Fórum; 2011.

3. Motta F, coordenador. Concurso público e Constituição. Horizonte (BH): Fórum; 2007.

4. Braga M. Seleção de pessoal: seus objetivos e seus problemas. Rio de Janeiro (RJ): Imprensa Nacional; 1945.

5. Viana A. DASP: Instituição a serviço do Brasil. Rio de Janeiro (RJ): Imprensa Nacional; 1953.

6. Pimentel AF. Da apuração ao merecimento. Rio de Janeiro (RJ): Imprensa Nacional; 1945.

7. Carvalho AC. Associação Brasileira de Enfermagem (1926-1976): Documentário. Brasília (DF): ABen; 1976.

8. Borges MCM. Editais de concursos públicos e seus elementos padrões diante dos princípios constitucionais. Rev Tribunal de Contas do Estado de Minas Gerais. 2009 Jan-Mar; 70(1):28-53.

9. Polit DF, Beck CT, Hungler BP. Fundamentos de Pesquisa em Enfermagem; Métodos, avaliação e utilização. $5^{\text {a }}$ ed. Porto Alegre (RS): Artmed; 2004.

10. JusBrasil - Educação Jurídica, Política e Gestão Pública [homepage na Internet]. Diários Oficiais da União [acesso 2013 Ago 7]. Disponível em: http:// www.jusbrasil.com.br/diarios/. 
11. Ministério da Saúde (BR). Conselho Nacional de Saúde. Resolução n. 466 de 12 de dezembro de 2012: diretrizes e normas regulamentadoras de pesquisa envolvendo seres humanos [Internet]. Brasília (DF): MS; 2012 [cited 2014 Jan 10]. Available from: http://conselho.saude.gov.br/resolucoes/2012/ Reso466.pdf

12. Departamento Administrativo do Serviço Público (BR). Portaria n. 1.360 de 18 de setembro de 1941: dispõe sobre as instruções especiais que regulam o Concurso de Provas para Provimento da Carreira Inicial de Enfermeiro em qualquer Ministério. Diário Oficial União 26 set.1941; Seção 1:18686-9.

13. Departamento Administrativo do Serviço Público (BR). Portaria n. 661 de 2 de julho de 1940: dispõe sobre as instruções gerais que regulam a realização de concursos para provimentos em cargo público federal. Diário Oficial União. 4 jul 1940. Seção 1:12757-8.

14. Departamento Administrativo do Serviço Público (BR). Portaria n. 1411 de 7 de outubro de 1941: dispõe sobre as instruções gerais que regulam a realização de concursos para provimentos em cargo público federal. Diário Oficial União. 15 out 1941. Seção 1:19899-900.

15. Ministério da Saúde (BR). Fundação Serviços de Saúde Pública. Enfermagem: legislação e assuntos correlatos. Rio de Janeiro (RJ): Guanabara; 1974.

16. Santos TCF, Barreira IA. A mulher e a enfermeira na nova ordem social do Estado Novo. Texto Contexto Enferm. 2008 Jul-Set; 17(3):587-93.

17. Campos PFS. Memorial de Maria de Lourdes Almeida: história e enfermagem no Brasil pós1930. Hist Cienc Saude-Manguinhos. 2013 Abr-Jun; 20(2):609-25.
18. Brasil. Decreto n. 1.963, de 13 de janeiro de 1940: dispõe sobre aproveitamento de ex-graduados do Exército e da Armada dos quadros do funcionalismo federal. Diário Oficial União. Seção 1 - 16 jan1940. Seção 1: 827.

19. São Paulo (Estado). Lei n ${ }^{\circ}$ 5.017, de 16 de dezembro de 1958: dispõe sobre a realização dos concursos e de provas de habilitação para provimento de cargos públicos de carreiras ou isolada e dá outras providências. Diário Oficial do Estado de São Paulo. 17 dez 1958; Seção 1:39.

20. Bessa MN, Amorim WM. Aspectos da formação profissional na Escola de Enfermagem Alfredo Pinto (1943-1949). Esc Anna Nery. 2006 Dez; 10(1):64-74.

21. Silva MRG, Gallian DMCG. A Escola de Enfermagem do Hospital São Paulo e seu primeiro currículo (19391942). Rev Bras Enferm. 2009 Mar-Abr; 62(2):317-22.

22. Costa LM, Germano RM. Estágio curricular supervisionado na Graduação em Enfermagem: revisitando a história. Rev Bras Enferm. 2007 NovDez; 60(6):706-10.

23. Mello CAB. Conteúdo Jurídico do Princípio da Igualdade. São Paulo (SP): Mallheiros;1995.

24. Mancia JR, Padilha MICS, Ramos FRS. Congresso Brasileiro de Enfermagem: sessenta anos de história. Rev Bras Enferm. 2009 Mai-Jun;62(3):471-49.

25. Fontenelle, José P. Compendio de Hygiene. Rio de Janeiro (RJ): Leite Ribeiro \& Maurillo; 1918.

26. Brasil. Decreto $n^{\circ} 9.808$, de 30 de 1942: altera as escalas de salários e as séries funcionais do pessoal extranumerário mensalista da União e dá outras providências. Diário Oficial União. 30 jun 1942. Seção 1: 10579.

27. Brasil. Junta de Corretores de Mercadorias do Distrito Federal. Mercado Disponível - Movimento do Dia 22. Diário Oficial União. 27 jun 1942. Seção 1: 10330. 